University of Nebraska - Lincoln

DigitalCommons@University of Nebraska - Lincoln

Publications, Agencies and Staff of the U.S.

Department of Commerce

U.S. Department of Commerce

2012

\title{
Starvation causes disturbance in amino acid and fatty acid metabolism in Diporeia
}

Suman Maity

Purdue University, smaity@purdue.edu

Amber Jannasch

Purdue University, hopfas@purdue.edu

Jiri Adamec

University of Nebraska-Lincoln, jadamec2@unl.edu

Thomas Nalepa

Great Lakes Environmental Research Laboratory, thomas.nalepa@noaa.gov

Tomas O. Höök

Purdue University, thook@purdue.edu

See next page for additional authors

Follow this and additional works at: https://digitalcommons.unl.edu/usdeptcommercepub

Part of the Environmental Sciences Commons

Maity, Suman; Jannasch, Amber; Adamec, Jiri; Nalepa, Thomas; Höök, Tomas O.; and Sepúlveda, Maria S., "Starvation causes disturbance in amino acid and fatty acid metabolism in Diporeia" (2012). Publications, Agencies and Staff of the U.S. Department of Commerce. 347.

https://digitalcommons.unl.edu/usdeptcommercepub/347

This Article is brought to you for free and open access by the U.S. Department of Commerce at DigitalCommons@University of Nebraska - Lincoln. It has been accepted for inclusion in Publications, Agencies and Staff of the U.S. Department of Commerce by an authorized administrator of DigitalCommons@University of Nebraska - Lincoln. 


\section{Authors}

Suman Maity, Amber Jannasch, Jiri Adamec, Thomas Nalepa, Tomas O. Höök, and Maria S. Sepúlveda 


\title{
Starvation causes disturbance in amino acid and fatty acid metabolism in Diporeia
}

\author{
Suman Maity ${ }^{\text {a }}$, Amber Jannasch ${ }^{\text {b }}$, Jiri Adamec ${ }^{c}$, Thomas Nalepa ${ }^{\text {d }}$, Tomas O. Höök ${ }^{\text {, }}$, Maria S. Sepúlveda ${ }^{\text {a,* }}$ \\ a Department of Forestry and Natural Resources, Purdue University, 195 Marsteller St., West Lafayette, IN, 47907, United States \\ b Bindley Bioscience Center at Discovery Park, Purdue University, 1203 W. State St. West Lafayette, IN 47907, United States \\ c Department of Biochemistry, Beadle Center N151, University of Nebraska, 1901 Vine Street, Lincoln, NE, 68588, United States \\ ${ }^{\mathrm{d}}$ National Oceanic and Atmospheric Administration (NOAA), Great Lakes Environmental Research Laboratory, 4840 S. State Road, Ann Arbor, MI, 48108, United States
}

\section{A R T I C L E I N F O}

Article history:

Received 6 October 2011

Received in revised form 22 December 2011

Accepted 29 December 2011

Available online 13 January 2012

\section{Keywords:}

Metabolomics

Two dimensional gas chromatography

Mass spectrometry

Amphipod

Great Lakes

\begin{abstract}
A B S T R A C T
The benthic amphipod Diporeia spp. was once the predominant macroinvertebrate in deep, offshore regions of the Laurentian Great Lakes. However, since the early 1990s, Diporeia populations have steadily declined across the area. It has been hypothesized that this decline is due to starvation from increasing competition for food with invasive dreissenid mussels. In order to gain a better understanding of the changes in Diporeia physiology during starvation, we applied two-dimensional gas chromatography coupled with time of flight mass spectrometry (GCXGC/TOF-MS) for investigating the responses in Diporeia metabolome during starvation. We starved Diporeia for 60 days and collected five organisms every 12 days for metabolome analyses. Upon arrival to the laboratory, organisms were flash frozen and served as control (day 0). We observed an increase in lipid oxidation and protein catabolism with subsequent declines of essential amino acids (proline, glutamine, and phenylalanine), down-regulation of glycerophospholipid and sphingolipid metabolism, and decreased polyunsaturated fatty acid abundance in nutritionally stressed Diporeia. Abundance of 1-Iodo-2methylundecane, a metabolite closely related to insect pheromones, also declined with starvation. This research has further substantiated the applicability of GCXGC/TOF-MS as a research tool in the field of environmental metabolomics. The next step is to apply this new knowledge for evaluating nutritional status of feral Diporeia to elucidate the underlying cause(s) responsible for their decline in the Great Lakes.
\end{abstract}

(c) 2012 Elsevier Inc. All rights reserved.

\section{Introduction}

Diporeia spp., a conglomerate of several poorly defined species, and glacial relict and freshwater amphipod, used to be the predominant benthic invertebrate in deep, offshore regions of the Laurentian Great Lakes (Cook and Johnson, 1974). The high lipid content in Diporeia makes it an ideal food resource for a number of fish species like lake whitefish (Coregonus clupeaformis), deepwater sculpin (Myoxocephalus thompsoni), and alewife (Alosa pseudoharengus). However, Diporeia populations have experienced precipitous declines throughout the Laurentian Great Lakes since the 1990s (Nalepa, 1998; Dermott, 2001; Lozano et al., 2001). The downfall in Diporeia numbers has been linked to the introduction and establishment of dreissenid mussels into the Great Lakes (Nalepa et al., 2005). Filter feeding activity by dreissenids may have removed substantial amounts of settling organic material (mainly diatoms) from the water column before reaching the lake bottom. Since Diporeia are

\footnotetext{
* Corresponding author at: Department of Forestry and Natural Resources and School of Civil Engineering, Purdue University, 195 Marsteller St., West Lafayette, IN, 47907, United States. Tel.: +1 765496 3428; fax: + 17654962422.

E-mail addresses: smaity@purdue.edu (S. Maity), hopfas@purdue.edu (A. Jannasch), jadamec2@unl.edu (J.Adamec), thomas.nalepa@noaa.gov (T. Nalepa), thook@purdue.edu (T.O. Höök), mssepulv@purdue.edu (M.S. Sepúlveda).
}

benthic feeders that inhabit the upper few centimeters of sediment (Marzolf, 1965; Johnson, 1987), it seems plausible that dreissenids are outcompeting Diporeia for the limited supply of available food. Lack of sufficient food could negatively impact Diporeia's survival as was the case with Monoporeia affinis, a related amphipod species from the Baltic Sea (Wiklund et al., 2008).

Little information is available on the physiological response of amphipods during starvation. One study found no significant changes in total lipid concentration in Diporeia starved for a month (Gauvin et al., 1989), whereas another study reported that M. affinis switched to lipid-based energy metabolism during starvation (Lehtonen, 1994). Since one of the plausible causes of Diporeia declines is starvation driven by food competition with dreissenid mussels, research aimed at studying impacts of prolonged starvation in Diporeia would be useful in providing insights on how persistent food deprivation can affect biological functions in Diporeia. Using a metabolomics approach, we previously reported on impacts in non-polar metabolites (histidine, glycerolipids, and sphingolipids) during starvation in this amphipod (Maity et al., 2012). The present study complements the previous one by reporting on changes in polar metabolites in starved Diporeia.

Metabolomics is the qualitative and quantitative study of metabolites present at any given time within a cell, organ, or organism. It is a "discovery" driven holistic evaluation of changes in the expression 
patterns of hundreds of metabolites after exposure to environmental stimuli (Nicholson et al., 2002). Compared to traditional approaches, metabolomics deals with a lower number (hundreds vs. thousands) of molecules (Wishart, 2005) which can result in improved interpretation of biological data (Bino et al., 2004; Dunn and Ellis, 2005). The application of metabolomics to understand environmental problems is a relatively new field and expanding rapidly (Viant, 2008). Environmental metabolomics has been successfully applied to study the impacts of pollutants and pathogens in fish (Samuelsson and Larsson, 2008) and terrestrial and aquatic invertebrates (Lin et al., 2006; Bundy et al., 2009; Schock et al., 2010), including Diporeia (Ralston Hooper et al., 2011). Multiple technological platforms have been developed over the past few years for metabolomics research, including Nuclear Magnetic Resonance (NMR), Mass Spectrometry (MS)-based Gas Chromatography (GC), and Liquid Chromatography (LC) coupled with MS (Sepúlveda et al., 2011). Two-dimensional gas chromatography based mass spectrometry (GCXGC/TOF-MS) has been used in conjunction with NMR or LC-MS to provide a more inclusive picture of metabolome changes. Although GCXGC/TOF-MS has been implemented to collect metabolic profiles from plants (Pongsuwan et al., 2008), microbes (Garcia et al., 2008), yeast (Mohler et al., 2006), and mice (Shellie et al., 2005), this metabolomics platform has been used considerably less compared to the more classic approaches (e.g., NMR).

In this paper, we describe the application of GCXGC/TOF-MSbased metabolomics to investigate the physiological responses of Diporeia during starvation. We hypothesize that prolonged starvation will result in disruption of lipid metabolism and progressive protein catabolism for energy production. In addition, we attempt to develop a "starvation metabolic profile" which may have a practical application for health assessment of declining Diporeia populations in the Laurentian Great Lakes.

\section{Materials and methods}

\subsection{Study animals}

In summer 2008, we collected live Diporeia from southern Lake Michigan (site C-5, 42' 49.00" N, 86' 50.00" W) at a depth of $157 \mathrm{~m}$ during a field cruise onboard National Oceanic and Atmospheric Administration's (NOAA) R/V "The Laurentian". Using ponar grabs, the top layer of the sediment was collected and sieved through a handheld mesh $(0.5 \mathrm{~mm})$ for the collection of live Diporeia. Animals were kept inside Nalgene $\odot 1 \mathrm{~L}$ bottles filled with pre-chilled $\left(4^{\circ} \mathrm{C}\right)$ lake water. Bottles were placed inside coolers on wet ice at $4{ }^{\circ} \mathrm{C}$ and brought to the laboratory where animals were allowed to acclimate for $48 \mathrm{~h}$ prior to the initiation of the experiments.

\subsection{Study design}

Before the start of the starvation study, a group of live animals ( $>$ $4 \mathrm{~mm}$ ) were flash frozen in liquid nitrogen and served as controls ("Day 0") . An ideal starvation experimental design would have also included a "positive control", i.e., a group that was fed. The most commonly used diet for maintaining Diporeia is "Tetramin" (fish flakes). However, no studies have tested the quality of this diet nor have developed a more species-specific diet (in our case, it would consist mostly of diatoms). Since this study was conducted, we have been successful at feeding them lyophilized diatoms (Maity et al. in review), but additional studies are needed in order to determine more specific nutrient requirements for this amphipod. The remaining animals were randomly assigned to one of six replicates $(n=10 /$ replicate). Each replicate consisted of a 1 L Pyrex@ glass beaker with $50 \mathrm{~g}$ ( $2 \mathrm{~cm}$ deep ) autoclaved Lake Michigan sediment (collected from C-5) and $700 \mathrm{ml}$ of reconstituted modified hard water (RMHW) (Ralston-Hooper et al., 2008). To simulate lake bottom conditions, the experiment was set-up inside a walk-in cooler with an ambient temperature of $4{ }^{\circ} \mathrm{C}$ and complete absence of light. No food was provided during the entire duration $(60 \mathrm{~d})$ of the experiment. At regular intervals of $12 \mathrm{~d}$, a subset of live specimens (4-6 total organisms per condition, one from each replicate and time period) was collected, flash frozen in liquid nitrogen and preserved at $-80{ }^{\circ} \mathrm{C}$ for later metabolomic analyses.

\subsection{Sample preparation}

Specimens were processed for metabolomic analyses following a modified protocol from Ralston-Hooper et al. (2008) as described below. Each biological replicate was composed of a single Diporeia $(0.0167 \mathrm{~g}-0.0055 \mathrm{~g})$. All reagents used were of analytical grade quality and were purchased from either Sigma Aldrich (St. Louis, MO, USA) or Regis Technologies (Morton Grove, IL, USA). Samples were prepared for metabolomics analyses as they thawed with the complete process, from retrieval of sample from sampling vial to homogenization, taking $\sim 2 \mathrm{~min}$, and carried while sample was kept on ice. Samples were homogenized for $20 \mathrm{~s}$ in pre-chilled $\left(4{ }^{\circ} \mathrm{C}\right)$ methanol $(300 \mu \mathrm{L})$ and MQ grade water $(150 \mu \mathrm{L})$ using a $7 \mathrm{~mm} \times 95 \mathrm{~mm}$ saw tooth stainless steel tissue homogenizer probe (Omni International, Marietta, GA, USA). Next, the homogenate was placed in a sonicator bath for $3 \mathrm{~min}$ to ensure uniform mixing. The solution was vortexed for 2 min after adding pre-chilled chloroform $(450 \mu \mathrm{L})$ and then it was placed on wet ice for an additional $10 \mathrm{~min}$. The chilled solution was then centrifuged at $3000 \times \mathrm{g}$ for $20 \mathrm{~min}$ to extract polar (methanol: water) and non-polar (chloroform) metabolites respectively. Each phase was pipetted into a new vial and was allowed to dry out at $45{ }^{\circ} \mathrm{C}$ using a Savant SPD 131DDA SpeedVac concentrator (Thermo Electron Corporation Milford, MA, USA). The chloroform phase was analyzed using LC/MS-TOF and the results of these analyses have been published elsewhere (Maity et al., 2012). The dried methanol: water extracted sample pellet (polar metabolites) was further derivatized using the following steps. First, methoxyamine hydrochloride $(20 \mathrm{mg}$ ) was dissolved in $1 \mathrm{~mL}$ anhydrous pyridine and $30 \mu \mathrm{L}$ of this solution was added to each pellet and mixed for $30 \mathrm{~min}$ at $60^{\circ} \mathrm{C}$. Next, $45 \mu \mathrm{L}$ of $\mathrm{N}$-methyl-N-(trimethylsilyl) trifluoroacetamide (MSTFA) was added and mixed for $1 \mathrm{~h}$ at $60^{\circ} \mathrm{C}$. The derivatized sample was transferred to an auto-sampler vial for GCXGC/TOF-MS analysis.

\subsection{Instrumental conditions}

Following derivatization, polar samples were analyzed on a Pegasus III GCXGC/TOF-MS (Leco Corporation, St. Joseph, MI, USA). Samples were injected $(2 \mu \mathrm{L})$ onto a two dimensional GC column with an inlet split-mode ratio of 20 and pre-set flow rate $(1.5 \mathrm{~mL} / \mathrm{min})$ of carrier gas (helium). The temperature in the inlet port was $280^{\circ} \mathrm{C}$. The dimensions of the two columns were as follows: first column, Restek Rtx-225 matrix $(0.25 \mathrm{~mm} \times 30 \mathrm{~m}, 0.25 \mu \mathrm{m})$, and second column, Agilent HP-5 matrix $(0.32 \mathrm{~mm} \times 2 \mathrm{~m}, 0.25 \mu \mathrm{m})$. The linear thermal gradient of the first column was between $50{ }^{\circ} \mathrm{C}$ and $240{ }^{\circ} \mathrm{C}\left(7^{\circ} \mathrm{C} /\right.$ min) followed by a $240{ }^{\circ} \mathrm{C}$ hold for $5 \mathrm{~min}$. The temperature of the second column was set as the same gradient with an additional offset of $+50{ }^{\circ} \mathrm{C}$. The TOF-MS analysis utilized electron impact ionization with an ion source temperature of $200{ }^{\circ} \mathrm{C}$ under the following conditions: detector voltage $1700 \mathrm{~V}$, electron energy $-70 \mathrm{~V}$, spectrum acquisition rate of $100 \mathrm{spectra} / \mathrm{s}$, and a detectable mass range of 30-800 Da. An acquisition delay of $150 \mathrm{~s}$ was applied at the start of the run.

\subsection{Data processing and statistical analysis}

Initial mass spectra were collected and processed in ChromaTOF software (version 3.32) from Leco Corporation followed by analyses 
using MSort@, an in-house software developed at the Bindley Biosciences Center at Purdue University (Oh et al., 2008). Since the same peak can generate multiple entries across different chromatograms, peaks were merged into a single entry and then aligned using retention time (RT) and similarity between fragmentation spectrums of merged peaks across different samples. The window size for the first and second RT dimensions were $1 \%$ and $5 \%$, respectively, and a minimum correlational value of 0.95 was set as threshold criteria. Metabolites were identified by comparing each spectrum against the National Institute of Standards and Technology (NIST) database of GC-MS spectra (http://www.nist.gov/srd/nist1.cfm). Each individual peak was compared against the library and assigned a similarity value (SV, a value of 1000 denotes a complete match). For any given peak, we set up a lower threshold of $\geq 750$ as potential match (Cristoni et al., 2009). Constant mean normalized data from GCXGC/ TOF-MS was subjected to multivariate analyses using $R \circledR$ statistical software (version 2.9.2, R Foundation for Statistical Computing, Vienna, Austria). Missing values are a common challenge in "omics" datasets (Chich et al., 2007; Karpievitch et al., 2010). For our dataset, missing values were replaced by the group average if present in at least half of the total samples per group, otherwise missing values were replaced by 1 (Colinge et al., 2005). Principal Component Analysis (PCA) was performed including the complete metabolome data (not just the statistical significant ones) to highlight any underlying structure in the data. Metabolite abundance was compared across treatments using ANOVA followed by Tukey's multiple comparison.

\section{Results and discussion}

Data fromD36 are not shown since organisms were lost during the sampling processing. Overall, mortality was less than $75 \%$. The results from the PCA revealed a distinct separation of metabolite expression patterns across starvation groups (Fig. 1). Regardless of the length of starvation (D12-D60), pre-starved animals (D0) were distantly grouped compared to the starved ones. The first three principal components helped explain more than half of the total variation (Fig. 2).

A total of eight metabolites were significantly changed during starvation (Table 1). These included L-proline, glutamine, Lthreonine, L-phenylalanine, N-acetyl glucosamine, hexadecanoic acid, trans-9-octadecenoic acid, and 1-Iodo-2-methylundecane.

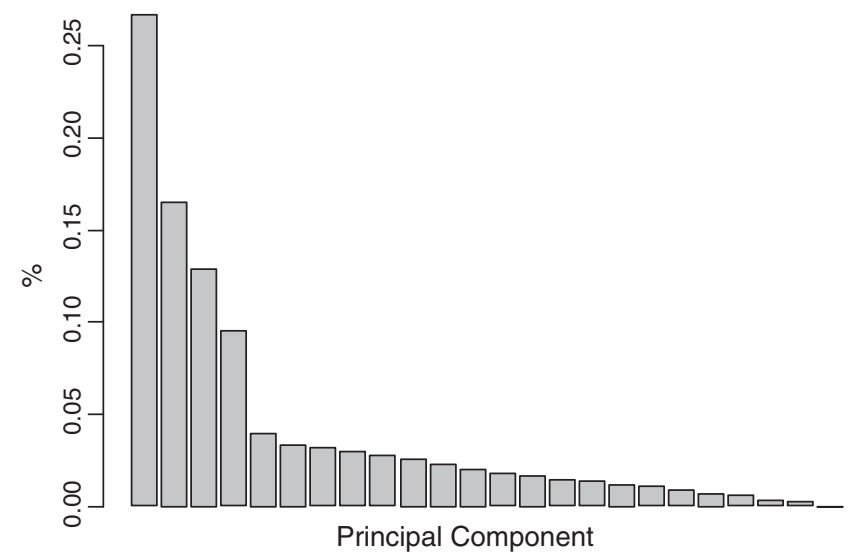

Fig. 2. Bar graph showing proportion of variation explained by each principal component (PC). The first three PC explained over $50 \%$ of the total variation in the data.

Fig. 3 presents the results of the multiple comparison tests for these metabolites. Each horizontal bar represents the difference between two starvation groups with $95 \%$ confidence interval. If the interval excludes 0 , then the difference is considered significant for that pairwise comparison. For example, abundance of glutamine and hexadecanoic acid (Fig. 3b and f) differed significantly in all starvation periods compared to Day 0 (in this case both increased, see Table 1).

Based on the significant metabolites detected using GCXGC/TOFMS (present study) and LC-MS (Maity et al., 2012) a "starvation metabolic pathway map" was constructed using canonical maps available from the Kyoto Encyclopedia of Genes and Genomes (http://www. genome.jp/kegg/) (Fig. 4).

We have provided a detailed picture of changes in the metabolome of Diporeia during starvation. As would be expected, several metabolic pathways were impaired, including metabolism of amino acids, amino sugars, fatty acids, and complex lipids (Fig. 4). From our previous study on metabolome changes in Diporeia using LC-MS (targeting non-polar metabolites, Maity et al., 2012), we further observed alterations in glycerophospholipid metabolism. A downregulation of glycerophospholipid and sphingolipid metabolism contributed to the disruption of the glycine-serine-threonine pathway

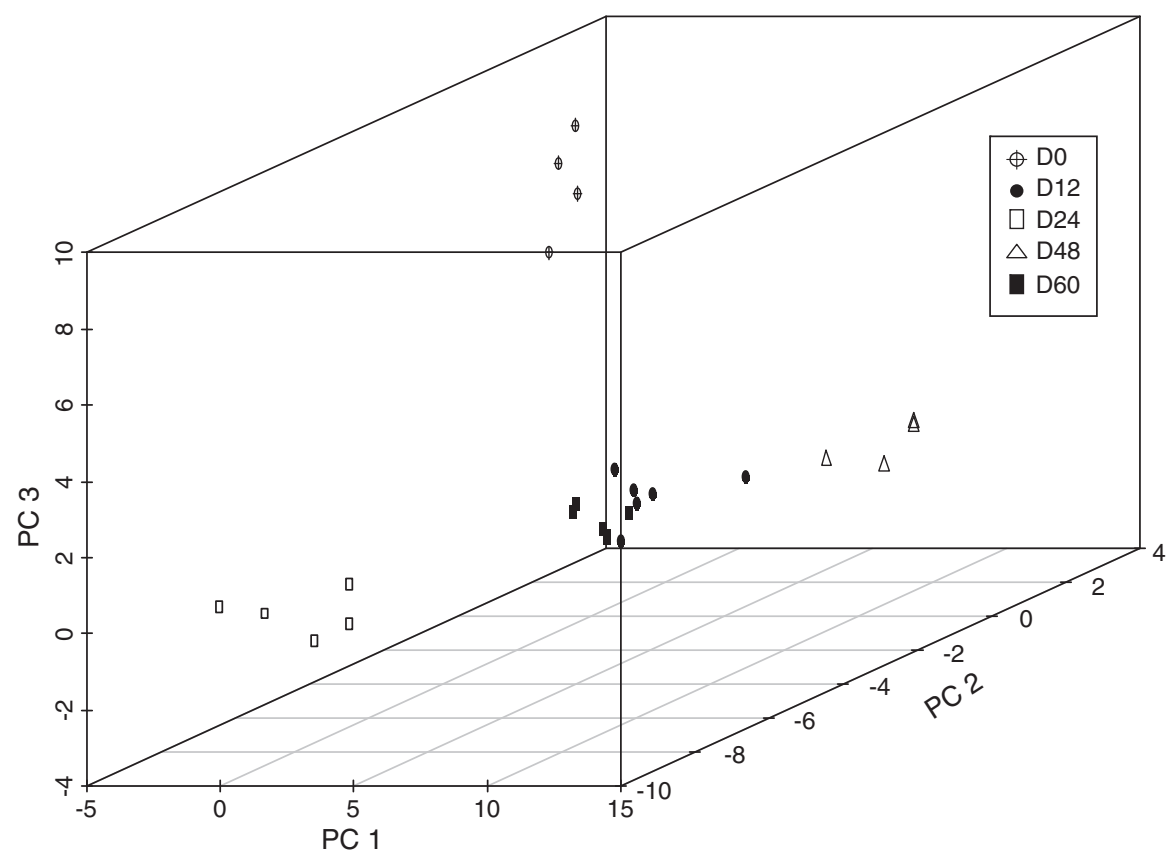

Fig. 1. Temporal changes in the metabolic profile of Diporeia under starvation. $\mathrm{D}=$ days in starvation. 
Table 1

List of significantly altered $(p<0.05)$ polar metabolites detected via GC $\times$ GC/TOF-MS in starved Diporeia.

\begin{tabular}{|c|c|c|c|c|c|c|c|}
\hline \multirow[t]{2}{*}{ Metabolite ID ${ }^{\mathrm{a}}$} & \multirow{2}{*}{$\begin{array}{l}\text { Peak } \\
\text { ID }^{\mathrm{b}}\end{array}$} & \multirow[t]{2}{*}{$\mathrm{SV}^{\mathrm{c}}$} & \multicolumn{5}{|c|}{ Mean expression level ${ }^{\mathrm{d}}( \pm \mathrm{SE})$} \\
\hline & & & Day 0 & Day 12 & Day 24 & Day 48 & Day 60 \\
\hline \multicolumn{8}{|l|}{ Amino acids } \\
\hline L-proline & 315 & 815 & $16.00 \pm 0.05$ & $15.47 \pm 0.19$ & $15.05 \pm 0.19$ & $14.65 \pm 0.17$ & $15.51 \pm 0.25$ \\
\hline Glutamine & 1063 & 819 & $4.52 \pm 3.52$ & $14.36 \pm 0.14$ & $14.00 \pm 0.24$ & $13.95 \pm 0.09$ & $14.06 \pm 0.01$ \\
\hline L-threonine & 149 & 781 & $14.71 \pm 0.15$ & $14.62 \pm 0.31$ & $14.41 \pm 0.14$ & $\mathrm{BLD}^{\mathrm{e}}$ & $14.74 \pm 0.11$ \\
\hline L-phenylalanine & 300 & 827 & $15.19 \pm 0.05$ & $14.52 \pm 0.52$ & $6.63 \pm 3.16$ & $12.95 \pm 0.09$ & $14.65 \pm 0.07$ \\
\hline \multicolumn{8}{|l|}{ Amino sugars } \\
\hline $\mathrm{N}$-acetylglucosamine & 399 & 763 & $13.32 \pm 0.29$ & $14.23 \pm 0.06$ & $6.08 \pm 2.84$ & $4.21 \pm 2.62$ & $13.67 \pm 0.10$ \\
\hline \multicolumn{8}{|l|}{ Fatty acids } \\
\hline Hexadecanoic acid & 267 & 810 & $2.77 \pm 1.77$ & $8.62 \pm 0.14$ & $8.59 \pm 0.13$ & $9.12 \pm 0.19$ & $8.97 \pm 0.24$ \\
\hline Trans-9-octadecenoic acid & 307 & 859 & $10.61 \pm 0.06$ & $10.72 \pm 0.14$ & $10.21 \pm 0.14$ & $10.04 \pm 0.10$ & $9.97 \pm 0.09$ \\
\hline \multicolumn{8}{|l|}{ Pheromone } \\
\hline 1-Iodo-2-methylundecane & 123 & 827 & $4.45 \pm 3.45$ & $15.58 \pm 0.04$ & $3.98 \pm 2.72$ & $15.30 \pm 0.02$ & $6.99 \pm 3.35$ \\
\hline
\end{tabular}

a Identification based on mass spectra match against National Institute of Standards and Technology (NIST) library.

b Based on the alignment results of metabolic peaks across different samples.

c Similarity value (SV) $>750$ was considered a positive match.

d Mean expression (log-transformed).

e Below detection limit starvation groups.

in starved Diporeia. Furthermore, the metabolism of several other amino acids, including methionine, lysine, histidine and glutamate, were also negatively impacted. In addition, starvation induced lipid oxidation and a concomitant decrease in FA biosynthesis. All together, these results suggest that starving Diporeia switch to protein catabolism after lipid reserves have been exhausted.

Concentrations of several amino acids changed during starvation in a time-specific manner (Table 1 and Fig. 3). For instance, the amino-acid L-proline declined during starvation (0-48 d, Fig. 3a).
The role of proline as a fuel source has been reported for a number of invertebrates (Scaraffia and Wells, 2003; Giulivi et al., 2008; Laparie et al., 2011). In a study conducted with the larval dragonfly Aeshna cyanea, proline along with glutamine, was found to be one of the main contributors of the free amino acid reserves used to meet energy demands during starvation (Herzog and Liappis, 1987). In Aeshna larvae, proline levels dropped immediately after a short starvation period $(10 \mathrm{~d})$ followed by an eventual rise after $30 \mathrm{~d}$ of starvation (Herzog and Liappis, 1987). These authors proposed that
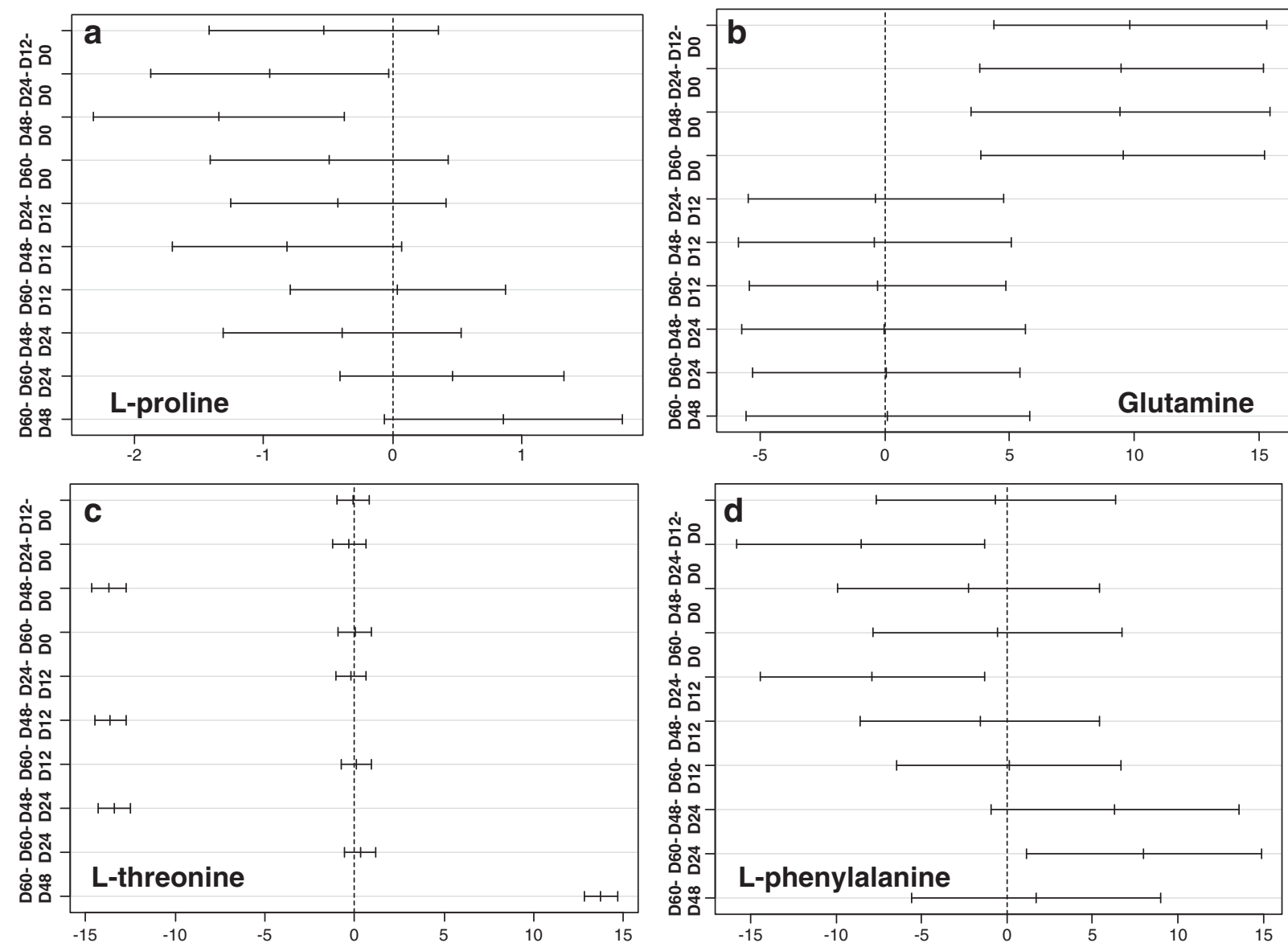

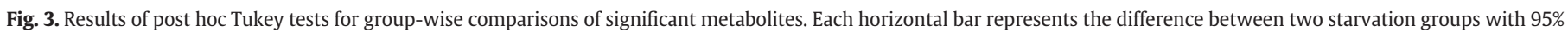
confidence interval. If the interval excludes 0 , then the difference is considered significant for that pair-wise comparison. 

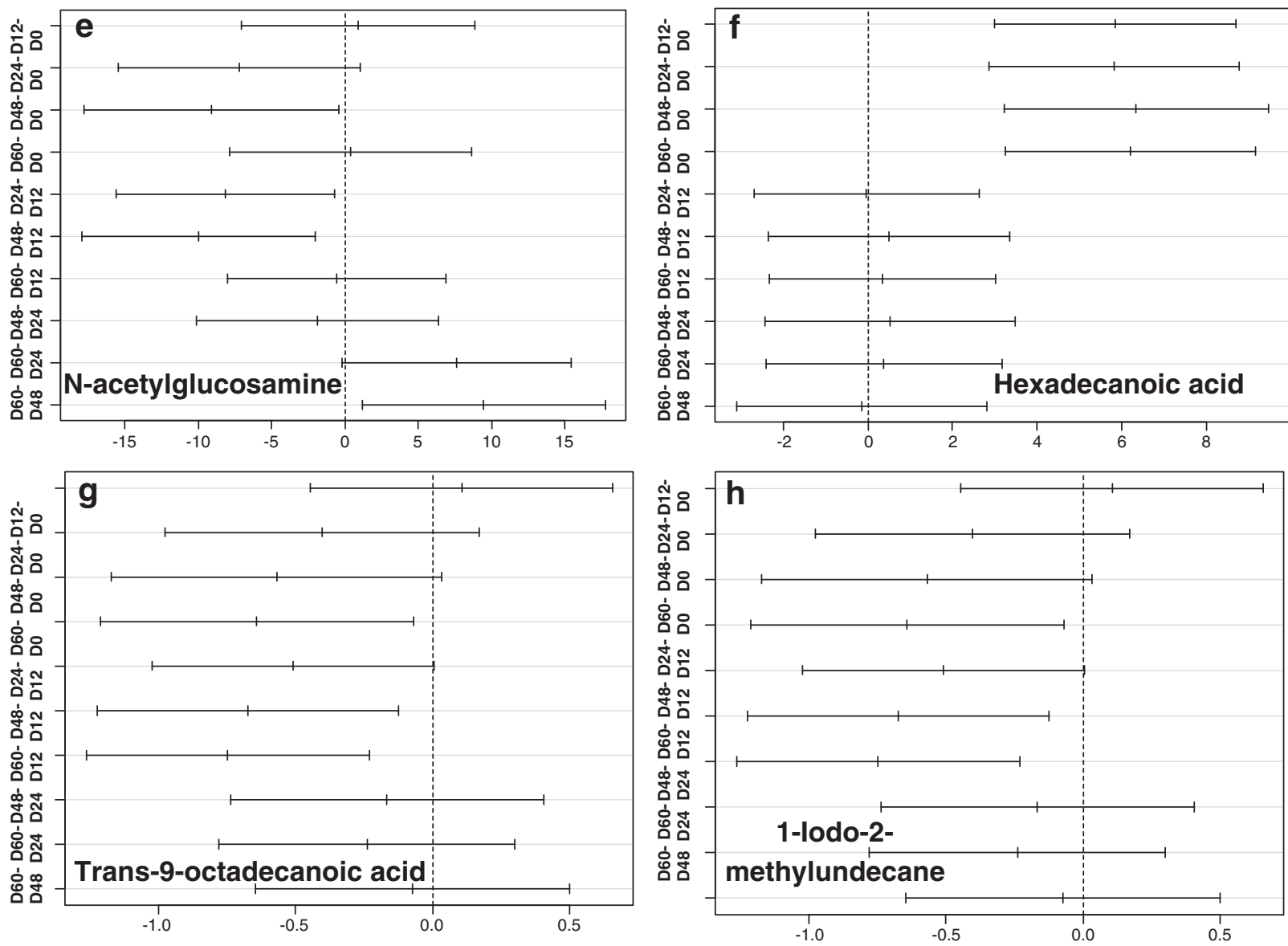

Fig. 3 (continued).

the larvae switched to protein-based metabolism after exhausting their carbohydrate reserves (Herzog and Liappis, 1987). We also observed a decrease in proline levels starting soon after the onset of starvation with a rise $60 \mathrm{~d}$ later. Proline is important for many other biological functions besides energy production. The presence of proline within the peptide chain regulates structural susceptibility to protease activity which in turn controls a multitude of biological functions (Yaron et al., 1993). Proline rich motifs are highly favorable as binding sites for modular domains (e.g., SH3, WW, EVH, WASP) which are important for intracellular communication. These proline binding domains form part of multi-domain molecules responsible for controlling cell growth, transcription rates, postsynaptic signaling, and cytoskeleton modifications. In relation to the latter, proline plays a crucial role in profilin function and actin polymerization which controls cytoskeletal movement. Proline rich motifs also control the degree of enzyme isomerization as well as offer phosphorylation and dephosphorylation reaction sites for proteins (Kay et al., 2000; Zarrinpar et al., 2003). Thus, disruptions in proline metabolism during starvation are likely to affect these processes in Diporeia. It is also important to note that alanine is the main precursor for proline synthesis in insects (Gade and Auerswald, 2002; Lorenz and Gade, 2009; Arrese and Soulages, 2010) and any changes in proline concentration are usually correlated with disruptions in alanine metabolism (Herzog and Liappis, 1987). Alanine is also an important osmolyte in crustaceans, essential for maintaining cellular ion balance (Abe et al., 1999). Thus, altered alanine metabolism could also result in an ionic imbalance in Diporeia.

The abundance of glutamine increased in starving Diporeia (Table 1, Fig. 3b). This amino acid is important as a stress response indicator (Tanguy et al., 2005; Hong et al., 2009; Leroy et al., 2010) and plays a crucial role in managing oxidative stress (Michaelis, 1998; Liu et al., 2000; Matés et al., 2002). This is because glutamine is a major constituent of the glutathione biosynthetic pathway and glutathione is key a reducing agent against reactive oxygen species (ROS) protecting the cell from oxidative damage and apoptotic cell death. The oxidation of the prolyl residues produces the glutamyl residues in the cell (Farr and Kogoma, 1991). Thus as a result of increased protein catabolism, more glutamine is accumulated which might disrupt glutathione synthesis and increase the risk of cell death. Glutamine is also crucial for the synthesis of a number of amino acids like proline, alanine and glycine (Fujimori and Abe, 2002). Both proline and glutamine are linked with arginine metabolism which in turn is related to alanine-aspartate-glutamate metabolism. These metabolic pathways are often looped together and regulate each other in an intricate fashion. In crustaceans, elevated glutamine levels are associated with enhanced nitrogen detoxification from protein metabolism (Chen and Chen, 2000).

L-phenylalanine is an important component of tyrosine metabolism and a neurotransmitter precursor (Meyers, 2000; Van Ruitenbeek et al., 2009). Additionally, in marine mussels, phenylalanine is one of the constituents of a protein complex which acts like metallothionein by binding to heavy metal ions (Roesijadi, 1981). Essential amino acids in crustaceans (valine, (iso)leucine, lysine, histidine, phenylalanine, threonine, arginine, methionine and tryptophan) are usually found in low abundance (Augusto et al., 2007). Of all these, phenylalanine is the most readily utilized amino acid in crustaceans. In the amphipod, Echinogammarus stammeri (freshwater scud), phenylalanine is an important controlling factor in the leucine transport pathway (Berra et al., 2006). The exact physiological role of phenylalanine in Diporeia is yet to be investigated but it is likely that phenylalanine can perform similar functions in neurotransmitter biosynthesis, regulate leucine uptake kinetics and/or 


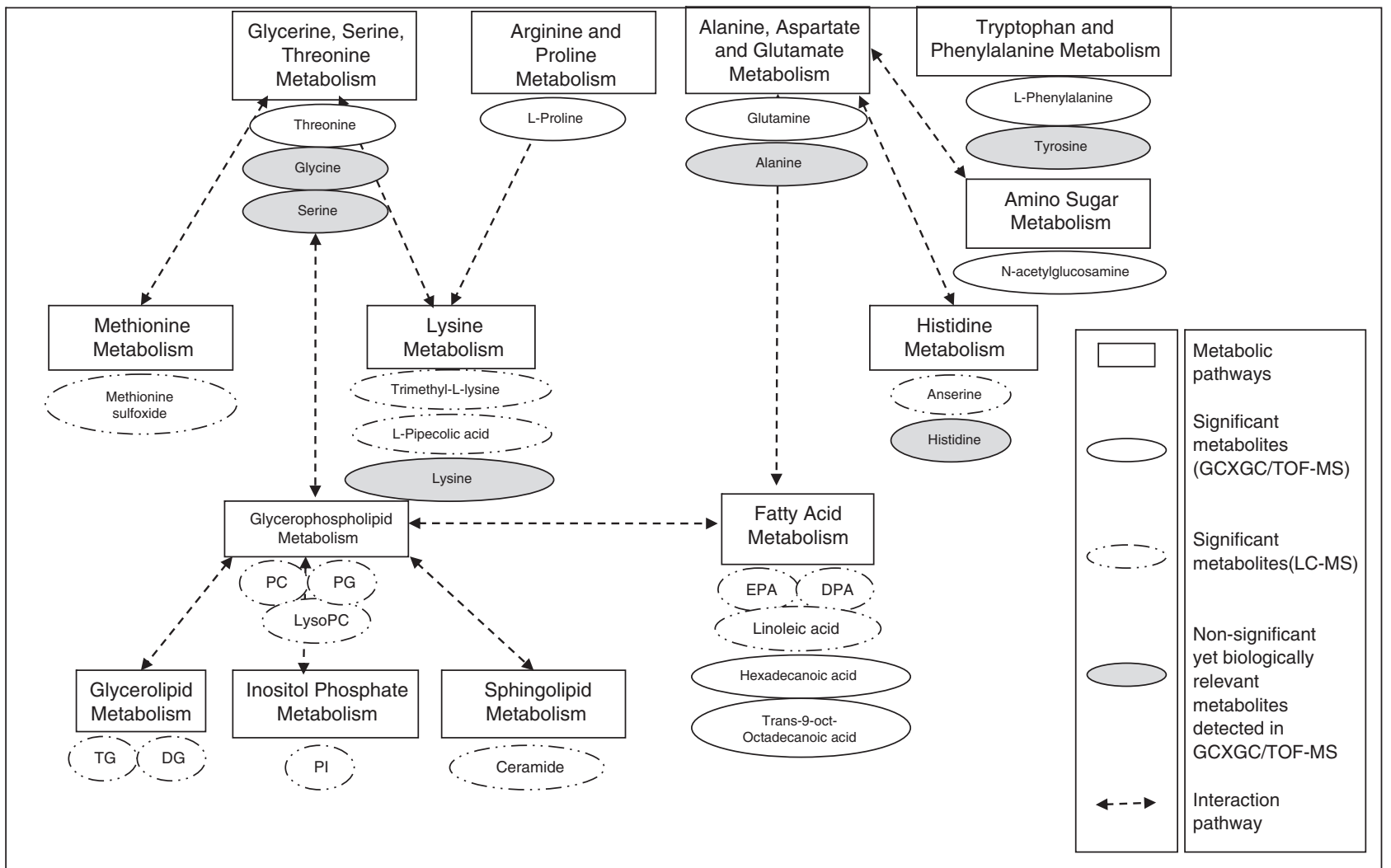

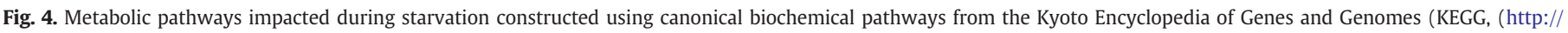

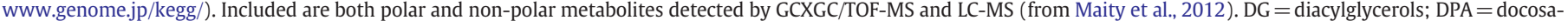

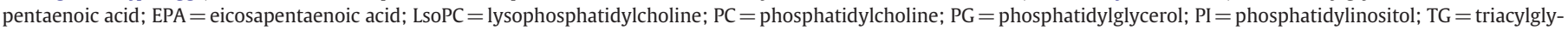
cerols; Thr $=$ threonine

impact tyrosine and phenylalanine pathways. Both proline and phenylalanine increased in starved Diporeia after $60 \mathrm{~d}$ of starvation. This "approximation" to baseline values might be an indication that "acclimation" or "adaptation" has taken place. Therefore, it would be of interest to follow metabolomic changes during starvation on these amphipods for longer time periods in order to capture potential "adaptive" responses to starvation. A potential "adaptive" response of Diporeia to a stressor such as starvation could be of great significance when considering the uncertain future of this organism in the Great Lakes. However, amino acid concentrations in crustaceans are quite variable, being influenced by several factors besides starvation, including stress and temperature (Graney and Giesy, 1986). Therefore, we believe our results should be further validated before any major conclusion is made.

Another biologically relevant metabolite identified was $\mathrm{N}$ acetylglucosamine, an amino sugar that plays a significant role in both inter- and intra-cellular interactions. It is a component of the glycocalyx, a cell surface component that participates in cell signaling. The charge distribution on these molecules as well as their flexibility to link up with one another has resulted in an excellent control of signal transduction. The ability of carbohydrate-based molecules (amino sugars) to maintain intercellular bonds and act as signal transduction mediators has been demonstrated in various taxa (Sharon, 2007; Netea et al., 2008; Sahly et al., 2008; Zhao et al., 2008; Dennis et al., 2009). N-acetylglucosamine is also found within the nuclear pore complex highlighting its importance for intracellular functions (Hanover, 2001). In most animals studied, N-acetylglucosamine is used to modify serine or threonine residues within the nuclear or cellular protein domains (Hart et al., 2007). Thus, N-acetylglucosamine can modify transcription factors and control protein trafficking. It can also act as regulator of cellular growth and proliferation in early stages of embryonic development (Hart et al., 2007). In invertebrates, amino sugars are also thought to play a key role in differentiating between self and non-self-recognition protecting host cells from attacks by their own immune systems (Rosenstiel et al., 2009; Vazquez et al., 2009) and are important for the synthesis of chitin, an important component of invertebrate exoskeleton (Cauchie, 2002). Therefore, long-term starvation has the potential to cause perturbed amino sugar metabolism in Diporeia which can lead to alterations in immune system functioning, reduced cellular integrity and intercellular communication and compromise the physical protection of their exoskeleton by disrupting cuticle production.

An interesting outcome of our studies has been the characterization of amino acid declines during starvation. Amino acids are essential for several functions including energy production, osmoregulation and muscle growth (Carefoot et al., 1992; Rosas et al., 2001; Huong et al., 2010; Karanova and Andreev, 2010). Our studies are in accordance with similar findings which found decreased levels of amino acids in crustaceans in the wild possibly due to starvation- like conditions (Rosa and Nunes, 2003, 2005; Mente et al., 2010). Thus, it can be concluded that in general, starved crustaceans respond with increased degradation of proteins and decrease in protein synthesis (Helland et al., 2000; Mente et al., 2002).

Concentrations of fatty acids such as hexadecanoic and trans-9octadecenoic acid also changed during starvation, but in opposite trends (Table 1, Fig. 3f and g). Compounds derived from hexadecanoic acid have been reported to perform a range of functions in insects. For example, both hexadecanoic acid and 3-oxo-(Z)-9-hexadecanal have been found in chemical secretions from termites (Prestwich and Collins, 1982; Chen et al., 1999), while triacontanyl hexadecanoate is important for cuticle formation in corn earworm (Helicoverpa zea) pupae (Buckner et al., 1996). Concentrations of hexadecanoic acid 
could be used as an indicator of progressive use of glycerolipids for energy production in starving Diporeia. Trans-9-octadecenoic acid is a breakdown product of linoleic acid metabolism and concentrations decrease during stress (Gardner, 1979, 1995), including exposure to contaminants (Jones et al., 2008). These results are in agreement with our findings and would suggest an increase in lipid metabolism during starvation.

An interesting finding was the detection of 1-Iodo-2-methylundecane (12MU). As far as we know, this is the first time that 1I2MU has been reported from crustaceans. This metabolite is believed to function as a sex pheromone and its production is estrogen-dependent (Achiraman et al., 2010a). A similar volatile compound, 1-iodoundecane, has been reported from cows during estrus (Achiraman et al., 2010b). Levels of this metabolite fluctuated widely during starvation with elevated levels in $\mathrm{d} 12$ and $\mathrm{d} 48$ while dropping in all other groups (Table 1).

In sum, our results have shown that nutritionally stressed Diporeia respond with an increase in lipid oxidation and protein catabolism (denoted by an increase in glutamine); declines of essential amino acids (proline, threonine, and phenylalanine); down-regulation of glycerophospholipid and sphingolipid metabolism; and a decrease in PUFA abundance (Fig. 4). Abundance of 1-Iodo-2-methylundecane, a metabolite closely related to insect pheromones, also decreased during starvation (24 d). Declines of these metabolites could impair reproductive function, growth, and ultimately long-term survival. These metabolite changes also result in a decrease of Diporeia's nutritional quality potentially impacting the health of fish that consume them. This research has further substantiated the applicability of GCXGC/TOF-MS as a research tool in the field of environmental metabolomics. The next step is to use this new knowledge for evaluating nutritional status of feral Diporeia and determine the underlying cause(s) responsible for their decline in the Great Lakes.

\section{Acknowledgements}

This research was supported by the Great Lakes Fisheries Trust (Grant \# 2008.886). We would also like to thank the crews of "The Laurentian" for their help during sample collection; Kimberly RalstonHooper for providing valuable input for the experimental set-up during its initial phase; Michael Gribskov for providing assistance with the statistical analyses; and Nicholas McCann and Payel Acharya for proving thoughtful suggestions for improving the manuscript.

\section{References}

Abe, H., Okuma, E., Amano, H., Noda, H., Watanabe, K., 1999. Role of free-and-alanine in the Japanese mitten crab Eriocheir japonicus to intracellular osmoregulation during downstream spawning migration. Comp. Biochem. Physiol. A Mol. Integr. Physiol. 123, 55-59.

Achiraman, S., Archunan, G., Ponmanickam, P., Rameshkumar, K., Kannan, S., John, G., 2010a. 1-Iodo-2 methylundecane [112MU]: An estrogen-dependent urinary sex pheromone of female mice. Theriogenology 74, 345-353.

Achiraman, S., Ponmanickam, P., Ganesh, D., Archunan, G., 2010b. Detection of estrus by male mice: synergistic role of olfactory-vomeronasal system. Neurosci. Lett. 477, 144-148.

Arrese, E.L., Soulages, J.L., 2010. Insect fat body: energy, metabolism, and regulation. Annu. Rev. Entomol. 55, 207-225.

Augusto, A., Greene, L.J., Laure, H.J., McNamara, J.C., 2007. The ontogeny of isosmotic intracellular regulation in the diadromous, freshwater palaemonid shrimps, Macrobrachium amazonicum and M. olfersi (Decapoda). J. Crustacean Biol. 27, 626-634.

Berra, E., Forcella, M., Giacchini, R., Parenti, P., 2006. Leucine transport across plasmamembranes from the scud Echinogammarus stammeri (Amphipoda: Gammaridae). Int. J. Limnol. 42, 79-85.

Bino, R.J., Hall, R.D., Fiehn, O., Kopka, J., Saito, K., Draper, J., Nikolau, B.J., Mendes, P., Roessner-Tunali, U., Beale, M.H., Trethewey, R.N., Lange, B.M., Wurtele, E.S., Sumner, L.W., 2004. Potential of metabolomics as a functional genomics tool. Trends Plant Sci. 9, 418-425.

Buckner, J.S., Mardaus, M.C., Nelson, D.R., 1996. Cuticular lipid composition of Heliothis virescens and Helicoverpa zea pupae. Comp. Biochem. Physiol. B Biochem. Mol. Biol. $114,207-216$.

Bundy, J.G., Davey, M.P., Viant, M.R., 2009. Environmental metabolomics: a critical review and future perspectives. Metabolomics 5, 3-21.
Carefoot, T., Taylor, B., Kalwa, S., Somogyi, G., Hughes, B., 1992. Effect of dietary d-amino acids on growth, survival, ammonia excretion and specific dynamic action in the supralittoral isopod, Ligia pallasii. Comp. Biochem. Physiol. A Physiol. 103 559-563.

Cauchie, H.M., 2002. Chitin production by arthropods in the hydrosphere. Hydrobiologia $470,63-95$.

Chen, J.M., Chen, J.C., 2000. Study on the free amino acid levels in the hemolymph, gill, hepatopancreas and muscle of Penaeus monodon exposed to elevated ambient ammonia. Aquat. Toxicol. 50, 27-37.

Chen, J., Henderson, G., Laine, R.A., 1999. Lignoceric acid and hexacosanoic acid: major components of soldier frontal gland secretions of the formosan subterranean termite (Coptotermes formosanus). J. Chem. Ecol. 25, 817-824.

Chich, J.F., David, O., Villers, F., Schaeffer, B., Lutomski, D., Huet, S., 2007. Statistics for proteomics: experimental design and 2-DE differential analysis. J. Chromatogr. B 849, 261-272.

Colinge, J., Chiappe, D., Lagache, S., Moniatte, M., Bougueleret, L., 2005. Differential proteomics via probabilistic peptide identification scores. Anal. Chem. 77, 596-606.

Cook, D., Johnson, M., 1974. Benthic macroinvertebrates of the St-Lawrence Great Lakes. J. Fish. Res. Board Can. 3, 763-782.

Cristoni, S., Molin, L., Lai, A., Bernardi, L.R., Pucciarelli, S., Agostini, M., Bedin, C., Nitti, D. Seraglia, R., Repetto, O., Dibari, V.F., Orlandi, R., Sinues, P.M.L., Traldi, P., 2009 MALDI-MS-NIST library approach for colorectal cancer diagnosis. Rapid Commun. Mass Spectrom. 23, 2839-2845.

Dennis, J.W., Lau, K.S., Demetriou, M., Nabi, I.R., 2009. Adaptive regulation at the cell surface by N-glycosylation. Traffic $10,1569-1578$.

Dermott, R., 2001. Sudden disappearance of the amphipod Diporeia from Eastern Lake Ontario, 1993-1995. J. Great Lakes Res. 27, 423-433.

Dunn, W.B., Ellis, D.I., 2005. Metabolomics: current analytical platforms and methodologies Trends Anal. Chem. 24, 285-294.

Farr, S.B., Kogoma, T., 1991. Oxidative stress responses in Escherichia coli and Salmonella typhimurium. Microbiol. Mol. Biol. Rev. 55, 561-585.

Fujimori, T., Abe, H., 2002. Physiological roles of free D-and L-alanine in the crayfish Procambarus clarkii with special reference to osmotic and anoxic stress responses. Comp. Biochem. Physiol. A Mol. Integr. Physiol. 131, 893-900.

Gade, G., Auerswald, L., 2002. Beetles' choice-proline for energy output: control by AKHs. Comp. Biochem. Physiol. B Biochem. Mol. Biol. 132, 117-129.

Garcia, D.E., Baidoo, E.E., Benke, P.I., Pingitore, F., Tang, Y.J., Villa, S., Keasling, J.D., 2008 Separation and mass spectrometry in microbial metabolomics. Curr. Opin. Microbiol. 11, 233-239.

Gardner, H., 1979. Lipid hydroperoxide reactivity with proteins and amino acids: a review. J. Agric. Food Chem. 27, 220-229.

Gardner, H., 1995. Biological roles and biochemistry of the lipoxygenase pathway. Hortscience 30, 197-204.

Gauvin, J.M., Gardner, W.S., Quigley, M.A., 1989. Effects of food removal on nutrient release rates and lipid content of Lake Michigan Pontoporeia hoyi. Can. J. Fish. Aquat. Sci. 46 $1125-1130$.

Giulivi, C., Ross-Inta, C., Horton, A., Luckhart, S., 2008. Metabolic pathways in Anopheles stephensi mitochondria. Biochem. J. 415, 309-316.

Graney, R.L., Giesy Jr., J.P., 1986. Seasonal changes in the free amino acid pool of the freshwater amphipod Gammarus pseudolimnaeus Bousfield (Crustacea: Amphipoda). Comp. Biochem. Physiol. A Physiol. 85, 535-543.

Hanover, J.A., 2001. Glycan-dependent signaling: O-linked N-acetylglucosamine. FASEB J. 15, 1865-1876.

Hart, G.W., Housley, M.P., Slawson, C., 2007. Cycling of O-linked -N-acetylglucosamine on nucleocytoplasmic proteins. Nature 446, 1017-1022.

Helland, S., Triantaphyllidis, G., Fyhn, H., Evjen, M., Lavens, P., Sorgeloos, P., 2000. Modulation of the free amino acid pool and protein content in populations of the brine shrimp Artemia spp. Mar. Biol. 137, 1005-1016.

Herzog, H.U., Liappis, N., 1987. The plasma composition of larval Aeshna cyanea MüllerII. The effect of the nutritional state on the free amino acids. Comp. Biochem. Physiol. A Physiol. 87, 47-52.

Hong, M., Chen, L., Qin, J.G., Sun, X., Li, E., Gu, S., Yu, N., 2009. Acute tolerance and metabolic responses of Chinese mitten crab (Eriocheir sinensis) juveniles to ambient nitrite. Comp. Biochem. Physiol. B Toxicol. Pharmacol. 149, 419-426.

Huong, D.T.T., Wang, T., Bayley, M., Phuong, N.T., 2010. Osmoregulation, growth and molting cycles of the giant freshwater prawn (Macrobrachium rosenbergii) at different salinities. Aquacult. Res. 41, e135-e143.

Johnson, R.K., 1987. The life history, production and food habits of Pontoporeia affinis Lindström (Crustacea: Amphipoda) in mesotrophic Lake Erken. Hydrobiologia $144,277-283$.

Jones, O., Spurgeon, D., Svendsen, C., Griffin, J., 2008. A metabolomics based approach to assessing the toxicity of the polyaromatic hydrocarbon pyrene to the earthworm Lumbricus rubellus. Chemosphere 71, 601-609.

Karanova, M., Andreev, A., 2010. Free amino acids and reducing sugars in the freshwater shrimp Gammarus lacustris (Crustacea, Amphipoda) at the initial stage of preparation to winter season. J. Evol. Biochem. Physiol. 46, 335-340.

Karpievitch, Y.V., Polpitiya, A.D., Anderson, G.A., Smith, R.D., Dabney, A.R., 2010. Liquid chromatography mass spectrometry-based proteomics: biological and technological aspects. Ann. Appl. Stat. 4, 1797-1823.

Kay, B.K., Williamson, M.P., Sudol, M., 2000. The importance of being proline: the interaction of proline-rich motifs in signaling proteins with their cognate domains. FASEB J. 14, 231-241.

Laparie, M., Larvor, V., Frenot, Y., Renault, D., 2011. Starvation resistance and effects of diet on energy reserves in a predatory ground beetle (Merizodus soledadinus; Carabidae) invading the Kerguelen Islands. Comp. Biochem. Physiol. A Mol. Integr. Physiol. 161, 122-129. 
Lehtonen, K.K., 1994. Metabolic effects of short-term starvation on the benthic amphipod Pontoporeia affinis Lindström from the northern Baltic Sea. J. Exp. Mar. Biol. Ecol. 176, 269-283.

Leroy, D., Haubruge, E., De Pauw, E., Thome, J., Francis, F., 2010. Development of ecotoxicoproteomics on the freshwater amphipod Gammarus pulex: identification of PCB biomarkers in glycolysis and glutamate pathways. Ecotoxicol. Environ. Saf. 73, 343-352.

Lin, C.Y., Viant, M.R., Tjeerdema, R.S., 2006. Metabolomics: methodologies and applications in the environmental sciences. J. Pest Sci. 31, 245-251.

Liu, J., Yeo, H.C., Övervik-Douki, E., Hagen, T., Doniger, S.J., Chu, D.W., Brooks, G.A. Ames, B.N., 2000. Chronically and acutely exercised rats: biomarkers of oxidative stress and endogenous antioxidants. J. Appl. Physiol. 89, 21-28.

Lorenz, M.W., Gade, G., 2009. Hormonal regulation of energy metabolism in insects as a driving force for performance. Integr. Comp. Biol. 49, 380-392.

Lozano, S.J., Scharold, J.V., Nalepa, T.F., 2001. Recent declines in benthic macroinvertebrate densities in Lake Ontario. Can. J. Fish. Aquat. Sci. 58, 518-529.

Maity, S., Jannash, A., Adamec, J., Gribskov, M., Nalepa, T., Höök, T., Sepúlveda, M.S. 2012. Metabolite profiles in starved Diporeia spp. using liquid chromatographymass spectrometry (LC-MS) based metabolomics. J Crustacean Biol.

Marzolf, G.R., 1965. Substrate relations of the burrowing amphipod Pontoporeia affinis in Lake Michigan. Ecology 46, 580-592.

Matés, J.M., Perez-Gomez, C., de Castro, I.N., Asenjo, M., Marquez, J., 2002. Glutamine and its relationship with intracellular redox status, oxidative stress and cell proliferation/ death. Int. J. Biochem. Cell Biol. 34, 439-458.

Mente, E., Coutteau, P., Houlihan, D., Davidson, I., Sorgeloos, P., 2002. Protein turnover, amino acid profile and amino acid flux in juvenile shrimp Litopenaeus vannamei: effects of dietary protein source. J. Exp. Biol. 205, 3107-3122.

Mente, E., Davidson, I., Karapanagiotidis, I.T., Fountoulaki, E., Nengas, I., 2010. Amino acid analysis in the shore crab Carcinus maenas (Decapoda: Brachyura). J. Crustacean Biol. 30, 643-650.

Meyers, S., 2000. Use of neurotransmitter precursors for treatment of depression. Alt. Med. Rev. 5, 64-71.

Michaelis, E.K., 1998. Molecular biology of glutamate receptors in the central nervous system and their role in excitotoxicity, oxidative stress and aging. Prog. Neurobiol. 54, 369-415.

Mohler, R.E., Dombek, K.M., Hoggard, J.C., Young, E.T., Synovec, R.E., 2006. Comprehensive two-dimensional gas chromatography time-of-flight mass spectrometry analysis of metabolites in fermenting and respiring yeast cells. Anal. Chem. 78, 2700-2709.

Nalepa, T., 1998. Dramatic changes in benthic macroinvertebrate populations in southern Lake Michigan. Aquat. Nuis. Sp. 4, 1-2

Nalepa, T.F., Fanslow, D.L., Messick, G., 2005. Characteristics and potential causes of declining Diporeia spp. populations in southern Lake Michigan and Saginaw Bay, Lake Huron. Great Lakes Fish Commun. Tech. Rep. 66, 157-188.

Netea, M.G., Brown, G.D., Kullberg, B.J., Gow, N.A.R., 2008. An integrated model of the recognition of Candida albicans by the innate immune system. Nat. Rev. Microbiol. 6, 67-78.

Nicholson, J.K., Connelly, J., Lindon, J.C., Holmes, E., 2002. Metabonomics: a platform for studying drug toxicity and gene function. Nat. Rev. Drug Discovery 1, 153-161.

Oh, C., Huang, X., Regnier, F.E., Buck, C., Zhang, X., 2008. Comprehensive twodimensional gas chromatography/time-of-flight mass spectrometry peak sorting algorithm. J. Chromatogr. A 1179, 205-215.

Pongsuwan, W., Bamba, T., Harada, K., Yonetani, T., Kobayashi, A., Fukusaki, E., 2008. High-throughput technique for comprehensive analysis of Japanese green tea quality assessment using ultra-performance liquid chromatography with timeof-flight mass spectrometry (UPLC/TOF MS). J. Agric. Food Chem. 56, 10705-10708.

Prestwich, G.D., Collins, M.S., 1982. Chemical defense secretions of the termite soldiers of Acorhinotermes and Rhinotermes (Isoptera, Rhinotermitinae). J. Chem. Ecol. 8, 147-161.

Ralston Hooper, K., Adamec, J., Jannash, A., Mollenhauer, R., Ochoa Acuña, H., Sepúlveda, M., 2011. Use of GC $\times$ GC/TOF MS and LC/TOF MS for metabolomic analysis of Hyalella azteca chronically exposed to atrazine and its primary metabolite, desethylatrazine. J. Appl. Toxicol. 31, 399-410.
Ralston-Hooper, K., Hopf, A., Oh, C., Zhang, X., Adamec, J., Sepúlveda, M.S., 2008. Development of GC $\times$ GC/TOF-MS metabolomics for use in ecotoxicological studies with invertebrates. Aquat. Toxicol. 88, 48-52.

Roesijadi, G., 1981. The significance of low molecular weight, metallothionein-like proteins in marine invertebrates: current status. Mar. Environ. Res. 4, 167-179.

Rosa, R., Nunes, M.L., 2003. Seasonal changes in nucleic acids, amino acids and protein content in juvenile Norway lobster (Nephrops norvegicus). Mar. Biol. 143, $565-572$.

Rosa, R., Nunes, M.L., 2005. Seasonal patterns of nucleic acid concentrations and amino acid profiles of Parapenaeus longirostris (Crustacea, Decapoda): relation to growth and nutritional condition. Hydrobiologia 537, 207-216.

Rosas, C., Cuzon, G., Gaxiola, G., Le Priol, Y., Pascual, C., Rossignyol, J., Contreras, F., Sanchez, A., Van Wormhoudt, A., 2001. Metabolism and growth of juveniles of Litopenaeus vannamei: effect of salinity and dietary carbohydrate levels. J. Exp. Mar. Biol. Ecol. 259, $1-22$.

Rosenstiel, P., Philipp, E.E.R., Schreiber, S., Bosch, T.C.G., 2009. Evolution and function of innate immune receptors: insights from marine invertebrates. Innate Immun. 1, 291-300.

Sahly, H., Keisari, Y., Crouch, E., Sharon, N., Ofek, I., 2008. Recognition of bacterial surface polysaccharides by lectins of the innate immune system and its contribution to defense against infection: the case of pulmonary pathogens. Infect. Immun. 76, $1322-1332$.

Samuelsson, L.M., Larsson, D.G.J., 2008. Contributions from metabolomics to fish research. Mol. Biosyst. 4, 974-979.

Scaraffia, P., Wells, M., 2003. Proline can be utilized as an energy substrate during flight of Aedes aegypti females. J. Insect Physiol. 49, 591-601.

Schock, T.B., Stancyk, D.A., Thibodeaux, L., Burnett, K.G., Burnett, L.E., Boroujerdi, A.F.B., Bearden, D.W., 2010. Metabolomic analysis of Atlantic blue crab, Callinectes sapidus, hemolymph following oxidative stress. Metabolomics 6, 250-262.

Sepúlveda, M.S., Ralston-Hopper, K.J., Sanchez, B.C., Hopf-Jannash, A., Baker, S.D., Diaz, N., Adamec, J., 2011. Use of proteomic and metabolomics techniques in ecotoxicological research. In: Casciano, D.A., Sahu, S.C. (Eds.), Handbook of Systems Toxicology. John Wiley and Sons Ltd, Chichester, UK, pp. 227-254.

Sharon, N., 2007. Lectins: carbohydrate-specific reagents and biological recognition molecules. J. Biol. Chem. 282, 2753-2764.

Shellie, R.A., Welthagen, W., Zrostliková, J., Spranger, J., Ristow, M., Fiehn, O., Zimmermann, R., 2005. Statistical methods for comparing comprehensive two-dimensional gas chromatography-time-of-flight mass spectrometry results: metabolomic analysis of mouse tissue extracts. J. Chromatogr. A 1086, 83-90.

Tanguy, A., Boutet, I., Moraga, D., 2005. Molecular characterization of the glutamine synthetase gene in the Pacific oyster Crassostrea gigas: expression study in response to xenobiotic exposure and developmental stage. Biochim. Biophys. Acta, Gene Struct. Expression 1681, 116-125.

Van Ruitenbeek, P., Sambeth, A., Vermeeren, A., Young, S., Riedel, W., 2009. Effects of Lhistidine depletion and L-tyrosine/L-phenylalanine depletion on sensory and motor processes in healthy volunteers. Br. J. Pharmacol. 157, 92-103.

Vazquez, L., Alpuche, J., Maldonado, G., Agundis, C., Pereyra-Morales, A., Zenteno, E., 2009. Review: Immunity mechanisms in crustaceans. Innate Immun. 15, 179-188.

Viant, M.R., 2008. Recent developments in environmental metabolomics. Mol. Biosyst. 4, 980-986.

Wiklund, A., Sundelin, B., Rosa, R., 2008. Population decline of amphipod Monoporeia affinis in Northern Europe: consequence of food shortage and competition? J. Exp. Mar. Biol. Ecol. 367, 81-90.

Wishart, D., 2005. Metabolomics: the principles and potential applications to transplantation. Am. J. Transplant. 5, 2814-2820.

Yaron, A., Naider, F., Scharpe, S., 1993. Proline-dependent structural and biological properties of peptides and proteins. Crit. Rev. Biochem. Mol. Biol. 28, 31-81.

Zarrinpar, A., Bhattacharyya, R.P., Lim, W.A., 2003. The structure and function of proline recognition domains. Sci. STKE 179, 1-10.

Zhao, Y.Y., Takahashi, M., Gu, J.G., Miyoshi, E., Matsumoto, A., Kitazume, S., Taniguchi, $\mathrm{N} ., 2008$. Functional roles of $\mathrm{N}$-glycans in cell signaling and cell adhesion in cancer. Cancer Sci. 99, 1304-1310. 